\title{
Sosyo-Kültürel Bir Olgu: Taziye Evlerine İlişkin Bilişsel Kurguların Belirlenmesi
}

\section{A Socio-Cultural Case: Determination of Cognitive Constructions Concerning Condolence Houses}

\author{
Selami Tanrıverdi a, ${ }^{\text {a, }}$, İhan Çiçek ${ }^{\mathrm{b}}$, Ersin Gültekin ${ }^{\mathrm{c}}$

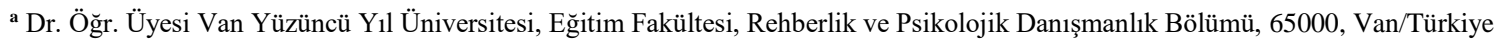 \\ ORCID: 0000-0003-0845-7219
}

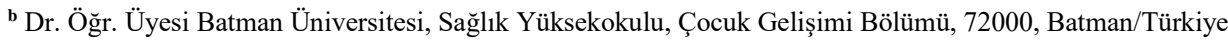
ORCID: 0000-0003-0266-8656

c Öğretmen, Van Özalp Sosyal Yardımlaşma ve Dayanışma Vakfi, Sosyal Yardım ve İnceleme Görevlisi, 65000, Van/Türkiye

\section{MAKALE BİLGİSİ}

Makale Geçmişi

Başvuru tarihi: 01 Kasım 2020

Düzeltme tarihi: 01 Şubat 2021

Kabul tarihi: 11 Şubat 2021

Anahtar Kelimeler:

Yas

Taziye evi

Kültürel olgu

\section{ARTICLE INFO}

Article history

Received August 01 November 2020

Received in revised form 03 February 2021

Accepted 11 February 2021

\section{Keywords:}

Mourning,

Condolence houses

Cultural phenomenon
ÖZ

$\mathrm{Bu}$ çalışmanın amacı kültürel bir olgu olan 'taziye evi' kavramına ilişkin bilişsel kurguların belirlenmesidir. Bu amaçla 2019-2020 güz döneminde Van ve Batman İllerinde ikamet etmekte olan ve daha önce taziye evlerinde bulunup deneyim sahibi olan 16 (on altı) yetişkin bireyden veriler toplanmıştır. Repertory Grid Tekniği ile katılımcıların taziye evi kavramına ilişkin bilişsel kurguları belirlenmiştir. Belirlenen bilişsel kurgular benzerliklerine göre sınıflandırılarak seslendirilmiştir. Böylelikle katılımcılara ait bilişsel kurgu grupları oluşturulmuştur. Oluşturulan kurgulardan hareketle katılımcıların her birinin puan değerleri üzerinden ağırlıklı ortalamaları hem katılımcı hem de cinsiyet bazlı belirlenmiștir. Sonuç olarak taziye evlerinin yas sürecinin sağlıklı yaşanması açısından birçok işlevi olduğu görülmüştür. Ayrıca bilişsel kurguların önem derecesi dikkate alındığında kadın ve erkek katılımcıların taziye evi kavramına ilişkin bilişsel kurgularında farklılıklar tespit edilmiştir.

\section{A B S T R A C T}

The aim of this study is to determine the cognitive constructs concerning the concept of "condolence houses" which is a cultural phenomenon. For this purpose, data were collected in the fall semester of 2019-2020 from 16 (sixteen) adults who were residing in Van and Batman provinces and had experience in condolence houses. The cognitive constructs of the participants concerning the concept of condolence houses were determined with Repertory Grid Technique. The determined cognitive constructs were classified and named according to their similarities. In this way, the participants' cognitive construct groups were formed. Based on the cognitive constructs created after this stage, the weighted averages of each participant's scores were determined on the basis of both participant and gender. As a result, it was concluded that condolence houses have many functions in terms of experiencing the mourning process in a healthy way. In addition, considering the importance degree of the cognitive constructs, differences were found in the cognitive constructs of the female and male participants concerning the concept of condolence houses.

\section{Giriş}

Ölen bireyin yokluğu, ailesi ve diğer yakınları tarafından kabullenilmesi biraz zaman alan bir durumdur. Çünkü ölüm gerçeğinin, ölen bireyin yakınlarında bıraktığı hissiyat olan "yas" yaşamın kaçınılmaz bir unsuru olarak durmaktadır. $\mathrm{Bu}$ bağlamda yas sürecindeki bireye başta ailesinin ve yakın arkadaşlarının, sonrasında ise sosyal çevresinde ilişkili olduğu insanların desteği şüphesiz bireyin yalnız olmadığının (Ataman ve Barış, 2019) ve acısının paylaşıldığının bir göstergesidir. Nitekim insanların ölüm gerçeği karşısında farklı duygulara kapılmaları, bu duyguları anlamaya ve zihinlerinde anlamlandirmaya

\footnotetext{
* Sorumlu yazar/Corresponding author

e-posta: selamitanriverdi@yyu.edu.tr
} 
çalışmaları sonucunda ortaya çıkan davranışlar zaman içinde kalıplaşmış uygulamalara dönüşmüş ve geleneksel ritüel özellikler kazanmıştır. Ölen bireyden sonra toplumsal hayatta onun ailesi ve yakınları tarafından gerçekleştirilen bir adet olan taziye de belirtilen uygulamalardan bir tanesidir (Albayrak ve Arıc1, 2007). Dolayısıyla toplumsal yaşamda öğrenilmiş davranışlar, bireyler vasıtasıyla sonraki nesillere ulaştırılarak toplumsal yapının sürekliliği sağlanır (Ertan, 2012). Nitekim tarihsel süreç içerisindeki toplumsal pratikler incelendiğinde ölüm seremonisinin farklı biçimlerde gerçekleştirilen törensel formlarla icra edildiği görülmektedir (Mumford, 2007).

Ölüm gerçeği, dünyadaki yaşamın sona ermesi açısından bireyi ilgilendiren, fakat öte yandan biyolojik yaşamı sona eren bireyin toplumsal yaşamda diğerleri ile kurduğu ilişki ağının sona ermesinin yarattığı etkileri gösteren seremonik yönüyle de sosyolojik bir olgudur (Tanhan ve İnci, 2009). Ölüm, hayatın ayrılmaz bir parçası olup insanoğlunun çağlar boyunca tanımlamaya çalıştığı bir gerçektir (Çiçek, 2020). Bu bağlamda ölüm, sosyal ve bireysel yaşamın rasyonel bir unsuru olduğu kadar fenomonolojik bir durum olarak da görülebilir. Dolayısıyla ölüme ilişkin farklı inanç, kültür ve uygarlıklarda farklı uygulama şekilleriyle karşılaşılması olağan bir durumdur. Çünkü karşılaşılan bu ölüm olgusu, yaşamanın fenomonolojik, gizemli, öngörülmez, acı veren ve korkutucu tarafinın içselleştirilmesi ve sosyolojik olarak toplumsallaştırılmasıdır (Dikmen, 2015). Dolayısıyla ölüm etrafında gerçekleştirilen söz konusu törensel şemanın büyük bir bölümünü "taziye" adı çerçevesinde sürdürülen pratikler oluşturmaktadır (Parin, Bilgili, Menak, 2012). Taziye ya da taziyet kelimesinin anlamına bakıldığında, lügatte "felaketli hallerde, üzüntüyü azaltacak sözler söyleme, yakını ölen kimseyi teselli etme, başsağlığı dileme" (Doğan, 2001: Akt: Parin, Bilgili, Menak, 2012) olarak tanımlandığı görülmektedir.

Üyesini kaybetmiş ailenin içinde bulunduğu toplumda yerini ve değerini koruyabilmesi için, başka şeylerin yanı sıra taziye sürecinde yaslarıyla ilgili ellerinden geldiğince yerine getirmesi gereken ritüeller bulunmaktadır (Örnek, 1979). Öncelikle taziye süreci camii hoparlörlerinden sela okunduktan hemen sonra 'ölen kişinin kimliği, akrabalık bağları, nerede ve ne zaman toprağa verileceği bilgilerini' içeren ve genellikle üç defa art arda seslendirilen bir anonsla başlar. Anonstan sonra taziyede bulunacak olanlar öncelikle mezarlığa giderler. Cenazenin defin işlemleri süresince -acının en yoğun yaşandığ 1 anlarda- taziye sahiplerine destek olarak, onların yanında olduklarını gösterirler. Defin işlemleri tamamlandıktan sonra bu merasime katılanlar önceden duyurusu yapılan taziye evine giderek taziyelerini bildirirler (Parin, Bilgili, Menak, 2012)

Toplumsal hayattaki modernleşme ile birlikte ortaya çıkan değişimler her şeyde etkili olduğu gibi ölüm ve sonrasında yürütülen faaliyetleri içeren taziye ritüelinde de değişikliğe yol açmıştır. Kentleşme hareketleri sonucunda ortaya çıkan apartman hayatı (Öncü, 1999) taziye merasimlerinin mekânı olan "kişiye ait evler" yerini kentsel yaşamın içselleştirilmesiyle birlikte "yerleşik ve bağımsız taziye evlerine" ve "mobil taziye çadırlarına" bırakmıştır (Parin, Bilgili, Menak, 2012). Yani taziye evi kültürü, kentlere yerleşen insanların birbirlerine destek olmak amacıyla ortaya çıkardığı yerler olmuştur (Demir, 2012). Çoğunlukla
Doğu ve Güneydoğu Anadolu Bölgelerinde görülen taziye evleri insanların acılarını kurumsal bir yapı şeklinde paylaştığı ortak alanlardır. Bu bağlamda bakıldığında taziye olgusu aynı zamanda dini, sosyal, insani ve ekonomik boyutları olan bir gelenektir. Bu yönüyle taziye evlerinin önemli bir işleve sahip olduğu, diğer bir ifadeyle tamamen toplumsal ihtiyaç doğrultusunda ortaya çıktığı görülmektedir. Nitekim taziye evleri, taziye sahiplerinin yaslarını sağlıklı yaşamaları için birçok açıdan kolaylık sağlayan işlevsel mekânlar olurken, bunun yanında taziyeye gelen insanlarda da dayanışma ruhunu canlı tutmaktadır (Yılmaz Çildam, 2020). Bu bilgilerden hareketle taziye evlerinin toplumsal ihtiyaçları karşılayan önemli bir mekân olarak görüldüğü (Coşkun ve Kayserili, 2019) ve dinsel yaşamı ölüm gerçeği üzerinden toplumsal açıdan daha da anlamlı (Kamuran, 2017) kıldığı söylenebilir. Bu yönüyle taziye evlerine başsağlığına gelen insanlar, taziye sahiplerinin hem acılarını paylaşmakta hem de taziye süresince yapılan hizmetlere katkı sunarak onlara destek olabilmektedirler. Dolayısıyla bu açıklamalardan hareketle taziye evlerinin, taziye sahiplerinin yas süreçlerini daha sağlıklı yaşamalarına yani daha kolay atlatmalarına katkı sağladığı söylenebilir.

Taziye evlerinin toplumsal yaşamdaki yerinin, öneminin ve etkilerinin belirlenmesi ancak taziye evlerinin yer aldığı yerlerde yaşayan kişilerin bilişsel kurgularının tespitiyle mümkün olabilecektir. Çünkü özellikle taziye evlerinin, kayıp yaşayan bireylerin yas süreçlerini sağlıklı bir şekilde yaşamaları için toplumsal bir dayanışma ve acının paylaşılması hususlarında önemli bir işlevi olduğu düşünülmektedir. $\mathrm{Bu}$ bağlamda bilişsel kurgular, kişilerin sahip oldukları tecrübe ve bilgileri arasında yer alan zihinsel bağıntıları gösterir. Bu araştırmada taziye evlerinin önem ve işlevlerini belirlemeye ilişkin çalışmaya katılan katılımcıların bilişsel kurgularını ortaya çıkarmak için repertory grid tekniği kullanılmıştır. Nitekim ifade edilen bilişsel kurguları ortaya çıkarmak için kullanılan repertory grid tekniği, ilk kez psikiyatrik yönden hasta olan kişilerin bireysel yapılarını görmek için Kelly (1955) tarafindan kullanılmıştır. $\mathrm{Bu}$ açıdan düşünüldüğünde repertory grid tekniği, bireyin sahip olduğu yargıları kapsayan olaylar, yaşantılar, alanı ile ilgili kendisinde gizli olan algıları görünür kılmaya çalışır. $\mathrm{Bu}$ bağlamda tanım olarak incelendiğinde, repertory grid, kişilerin bilişsel kurgularını yani kendilerine ait olan algılarını ortaya çıkarma amacıyla kullanılan özgün bir görüşme tekniğidir. Kelly’nin ortaya çıkarmış olduğu 'Kişisel Yapı Psikolojisi' kapsamında Repertory grid tekniğinin anlaşılması gerekmektedir. Kişisel Yapı Psikolojisi'ne göre, her birey, kendine özgü kavramsal sistemleri veya bilişsel kurguları geliştirir. Bilişsel kurgular olarak ifade edilen, bu bireye özgü yapılar, iki kutuplu (pozitif-negatif), süreğen bir yapıdadırlar (Shaw ve Gaines, 1993). Kişiler tecrübe ve bilgileri yoluyla zihinlerinde oluşturmuş oldukları bu bilişsel kurgular vasitasıyla, diğerleri ile iletişime geçer ve dünyayı anlamlandırmaya çalışırlar. Dolayısıyla bireylerin deneyim ve sahip oldukları bilgiler doğrultusunda iç dünyalarında oluşturdukları bilişsel kurgularının günlük yaşamlarını etkileyebilme durumu göz önüne alındığında, toplumda yer ve anlam edinen taziye evlerine ilişkin katılımcıların sahip oldukları bilişsel algıları belirlemenin önem arz ettiği düşünülmektedir. 
Taziye evlerine ilişkin elde edilecek bilişsel kurgularda, toplumsal yaşamda gerçekleşen yas sürecinin sağlıklı bir şekilde atlatılmasında rol oynayan psikolojik etkilerin belirlenmesinin doğrudan veya dolaylı veriler sağlayacağ düşünülmektedir. Buna göre katılımcıların, sosyo-kültürel bir olgu olan taziye evlerine ilişkin sahip oldukları bilişsel kurguların belirlenmesi bu çalışmanın amacını oluşturmaktadır. $\mathrm{Bu}$ amaç doğrultusunda araştırmada aşağıda yer alan sorulara cevap aranmıştır.

Katılımciların;

-Taziye evi kavramına ilişkin sahip oldukları bilişsel kurgu grupları nelerdir?

-Cinsiyet değişkenine göre taziye evlerine ilişkin bilişsel kurgu grupları nelerdir?

-Taziye evine ilişkin sahip oldukları bilişsel kurgular arasında, görece önemli gördükleri bilişsel kurgu grupları nelerdir?

\section{Yöntem}

\subsection{Araştırmanın Modeli}

$\mathrm{Bu}$ çalışma nitel bir araştırmadır. Nitel araştırmalar, araştırmacıların incelemek istedikleri konu veya konuları kendi doğal ortamlarında inceledikleri, bu konunun olgusunu anlamlaştırdıkları ve yorumladıkları araştırma yöntemleridir (Yıldırım ve Şimşek, 2000). Nitel araştırmaların bir kısmı, belli bir teoriden hareket etme yerine, kavram ya da olgunun kişinin zihninde yer aldığı biçimiyle ilgilenir. Bu çalışmada, taziye evi olgusuna ilişkin kişinin zihninde var olanı elde etmeye odaklanıldığından araştırmada nitel araştırma yöntemlerinden fenomenolojik desen kullanılmıştır. Fenomenolojik desenler çoğunlukla kişinin iç dünyasını oluşturan bilinç yapılarını ortaya koymaya yöneliktir (Mayring, 2000, Tanhan, 2018). Fenomenolojik çalışmalar, insanların iç dünyalarında gizledikleri olguların ortaya çıkmasını sağlar. Böylece bireyin niyetlerini ve düşünce yapılarını anlamaya çalıştığı söylenebilir.

\section{2. Çalışma Grubu}

Araştırmanın çalışma grubunu 2019 yılında Van ve Batman illerinde taziye evlerinin yer aldığ kişilerden çalışmaya katılmaya gönüllü olan bireylerden oluşturulmuştur. Katılımda bir temel ölçüt dikkate alınmıştır. $\mathrm{Bu}$ ölçüt daha önce bir kez olsa bile taziye evinde bulunmuş olmak ölçütüdür. Araştırmaya katılımda ifade edilen ölçütü yerine getiren ve araştırmaya katımda gönüllülük gösteren katılımcılar arasından seçkisiz olarak belirlenen 8 (sekiz) kadın ve 8 (sekiz) erkek olmak üzere toplamda 16 yetişkin katılımcı araştırmanın çalışma grubunu oluşturmuştur. Ayrıca araştırmanın etik ilkelere uygunluğu için Van Yüzüncü Yıl Üniversitesi Sosyal ve Beşeri Bilimleri Yayın Etik Kurul Başkanlığına başvuruda bulunulmuş, etik açıdan bir sakınca olmadığına ilişkin 01.04.2020 tarihli ve 25474 sayılı etik kurul uygunluk belgesi araştırmanın sonunda EK-1'de verilmiştir.

\subsection{Veri Toplama Araçları}

\subsubsection{Repertory Grid Ölçme Formu}

Araştırmada veriler basit repertory grid görüşme tekniği ile toplanmıştır. Bu amaçla araştırmada Repertory Grid Ölçme Formu (RGF) kullanılmıştır. RGF, Gömülü Kuram olarak bilinen (Grounded Theory)'nin kabulleri doğrultusunda geliştirilen bir formdur. Bu form kişinin belli bir konuda sahip olduğu bilişsel kurguyu belirlemeye dönük olarak kullanılır. Literatürde var olan farklı repertory görüşme formlarından basit repertory görüşme formu kullanılmıştır. $\mathrm{Bu}$ çalışmada da "repertory grid"in modellemesine uygun olarak (Morrison, 1990; Tanhan, 2018) araştırmacıların oluşturdukları RGF kullanılmıştır.

Yapılandırılmış görüşme tekniği ile ilişkili geliştirilen RGF, değişik işlem aşamalarından oluşmaktadır (Fransella, Bell ve Bannister, 2004). Dolayısıyla belli işlemler yapıldığında, katılımcılarda gömülü yani saklı olan belli bilişsel kurgular açığa çıkarılır. Kişinin sahip olduğu tecrübelere dayalı olarak gömülü bilişsel kurgular oluşturulur. Bu bağlamda, "repertory grid tekniği”"nin uygulanabilmesi için temel ölçüt, araştırmaya katılacak kişilerin ele alınacak konu ile ilgili az da olsa bir deneyim edinmiş olmalarıdır. Araştırmada kullanılan RGF'ye ait örnek Tablo 1'de gösterilmiştir.

Tablo 1: Örnek Repertory Grid Görüşme Formu

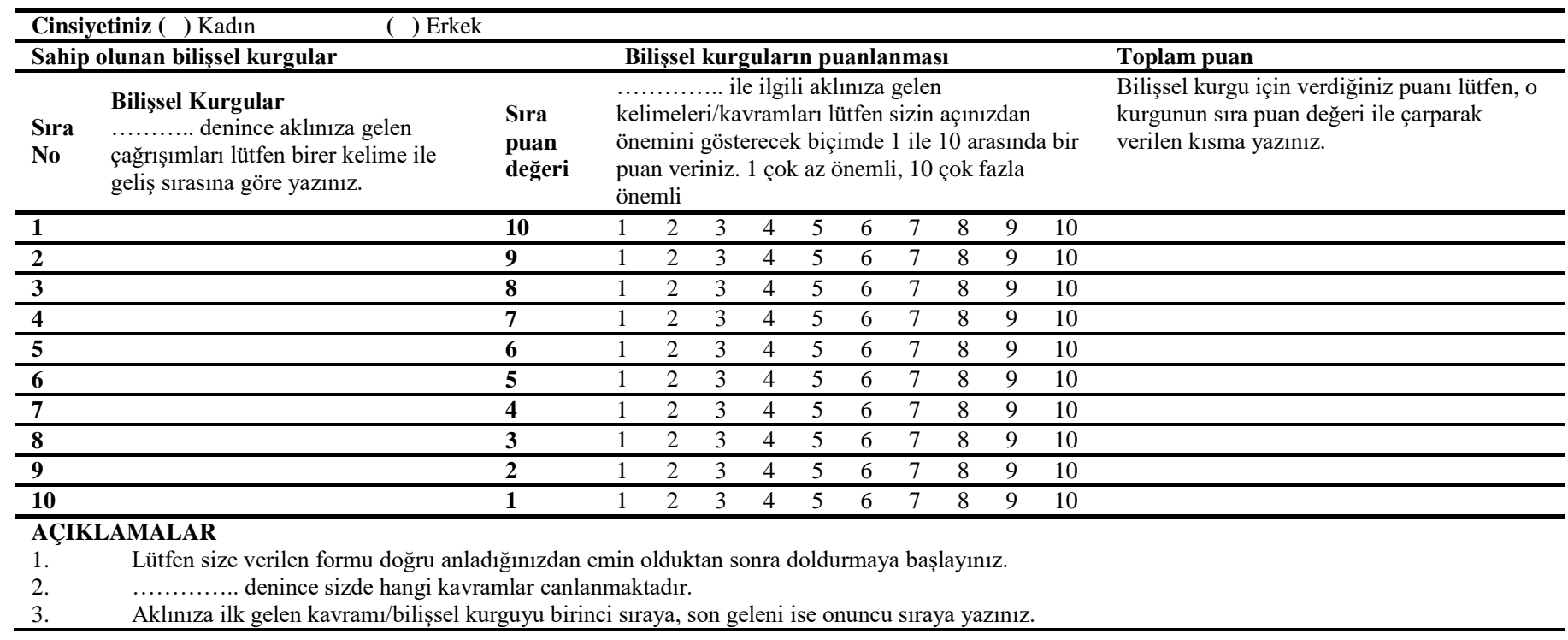

Tablo 1'de katılımcıların cinsiyetlerine ilişkin veriler de RGF'ye entegre biçimde toplanmıştır. 


\subsection{Verilerin Toplanması ve Çözümlenmesi}

Araştırmada öncelikle katılımcılara görüşme formu dağılmıştır. Katılımcıların RGF'yi doldururken birbirlerinden etkilenmemeleri için gerekli açılama yapılmış ve birbirlerinden belli bir mesafede oturmaları istenmiştir. Daha sonra formun nasıl doldurulacağ 1 ayrıntılı bir biçimde katılımcılara açıklanmış ve katılımcıların formun üzerinde bulunan açıklamaları okumaları ve anlamakta zorlandıkları bir nokta olup olmadığı sorulmuştur. Katılımcıların hazır olmasından sonra, RGF doldurulması aşamasına geçilmiştir. Katılımcı RGF doldurma süre aralığı beş dakika ile on beş dakika arasında olmuştur.

Araştırmanın ilk bölümünü ele alınan olgunun açıklamasının yapılması yani tanımlanması oluşturmaktadır. Olgunun tanımının yapılması araştırmanın sağlıklı yapılabilmesi için oldukça önemlidir. $\mathrm{Bu}$ araştırmanın olgusu da, taziye evlerine ilişkin bilişsel algılarıdır. Bu amaçla RGF ile katılımcıların taziye evlerine ilişkin bilişsel kurguları belirlenmiştir. Fakat 'Repertory Grid Tekniği', farklı işlem aşamalarından geçmektedir (Adams-Weber, 1989; Creswell, 1998; Fransella, Bell ve Bannister, 2004; Melrose ve Shapiro, 1999; Tanhan, 2018). İlk aşamada araştırmaya gönüllü katılanlardan taziye evi denilince akıllarına gelen bilişsel kurguları akıllarına geliş sırası ile RGF'ye yazmaları; daha sonra belirtildiği biçimde puanlamaları istenmiştir. Daha sonra katılımcıların bilişsel kurgularının toplam değeri belirlenmiştir. $\mathrm{Bu}$ aşamadan sonra, üretilen bilişsel kurgular benzerliklerine göre sınıflandırılarak seslendirilmiștir. Böylelikle katılımcılara ait bilişsel kurgu grupları oluşturulmuştur. $\mathrm{Bu}$ aşamadan sonra oluşturulan kurgulardan hareketle katılımcıların her birinin puan değerleri üzerinden ağırlıklı ortalamaları hem katılımcı hem de cinsiyet bazlı belirlenmiştir (Fransella, Bell ve Bannister, 2004; Tanhan, 2018). Bu işlemler tüm katılımcılar için yapılmasının yanında, kadın ve erkek katılımcılar için ayrı ayrı da gerçekleştirilmiştir.

\section{Bulgular}

$\mathrm{Bu}$ bölümde, katılımcıların taziye evlerine ilişkin sahip oldukları bilişsel kurgular, öncelikle benzerlik düzeylerine göre kategorilere ayrılmış ve tüm katılımcılara ait bilişsel kurguların görece önem düzeyi belirlenmiştir. Sonrasında ise katılımcıların taziye evlerine ilişkin sahip oldukları bilişsel kurgular, cinsiyet değişkenine göre bilişsel kurgu kategorileri ve görece önem düzeyi belirlenerek, kadın ve erkek katılımcılar açısından bilişsel kurguların görece önem düzeyi karşılaştırılmıştır. Katılımcıların ürettikleri bilişsel kurguların benzerliklerine göre ayrıldıkları bilişsel kurgu grupları aşağıda Tablo 2'de yer almaktadır.

Tablo 2: Tüm Katılımcılara Ait Bilişsel Kurgular

\begin{tabular}{|c|c|c|}
\hline \multicolumn{3}{|c|}{ ÖLÜM ve YAS } \\
\hline Kayıp 1kk. 1, 10x7=70 & Ölüm 6kk. $3,8 \times 10=80$ & Ölüm 7ek. 1, 10x10= 100 \\
\hline Cenaze 2.kk. $1,10 \times 5=50$ & Ölüm 7kk. 1, 10x10= 100 & Ölüm 8ek. $6,5 \times 10=50$ \\
\hline Ölüm 2kk. 2, 9x10=90 & Ölüm 8kk. 1, 10x6= 60 & Kurtuluş/son 3 kk. $8,3 \times 7=21$ \\
\hline Fani dünya $2 \mathrm{kk} .6,5 \times 10=50$ & Ölüm 1ek. 1, 10x10= 100 & Ayrılık/son 4kk. $6,5 \times 7=35$ \\
\hline Ölüm 3kk. 1, 10x10= 100 & Ölüm 2ek. 2, 9x10=90 & Geride birakma $1 \mathrm{kk} .7,4 \times 6=24$ \\
\hline Yas 5kk. 1, 10x10= 100 & Ölüm 4ek. 2, 9x10=90 & Fani olma/ölümlü olma 8kk. 5, 6x9= 54 \\
\hline Ölüm 5kk. 3, 8x10= 80 & Yas tutma 4ek. $7,4 \times 9=36$ & Geçicilik 8kk. 8, 3x10=30 \\
\hline Yaşamın sonu 5kk. 5, 6x10=60 & Ölüm 5ek. 1, 10x10= 100 & Gereksiz/geçici mevkiler 2kk. 8, 3x7=21 \\
\hline Hayatın anlamsızlığ 1 ek. $6,5 \times 8=$ & & \\
\hline \multicolumn{3}{|c|}{ HÜZÜN, AĞLAMA ve ACI ÇEKME } \\
\hline Hüzün 1kk. 2, 9x9=81 & Üzüntü 4kk. 3, 8x9=72 & Hasret giderme $8 \mathrm{kk} .9,2 \times 9=18$ \\
\hline Ağlama $1 \mathrm{kk} .6,5 \times 9=45$ & Ac1-keder 5kk. 2, 9x10=90 & Hüzün 1ek. 2, 9x9=81 \\
\hline Karamsarlik 1kk. 8, 3x7=21 & Geride kalanların acıs $15 \mathrm{kk} .10,1 \times 10=10$ & Üzüntüler 2ek. 5, 6x7= 42 \\
\hline Ac1 $2 \mathrm{kk} .4,7 \times 9=63$ & Tefekkür 6kk. $8,3 \times 8=24$ & Anıların canlanması 3 ek. $9,2 \times 8=16$ \\
\hline Mutsuzluk 3kk. 2, 9x1 =9 & Ac1 7 kk. $3,8 \times 10=80$ & Üzüntüleri dinlemek 6ek. 8,3 x8= 24 \\
\hline Üzüntü 3kk. 3, 8x7= 56 & Anma 8kk. $2,9 \times 7=63$ & Acısını hatırlama 7 ek. $8,3 \times 10=30$ \\
\hline Gözyaşı 3kk. $6,5 \times 10=50$ & Üzüntü 8kk. $6,5 \times 7=35$ & Üzüntü 8ek. 4, 7x7= 49 \\
\hline \multicolumn{3}{|c|}{ ÖLÜM KORKUSU, DUA VE AHİRETE İNANCI } \\
\hline Ahiret inanc1 $2 \mathrm{kk} .7,4 \times 10=40$ & Ahiret 5kk. 4, 7x8=56 & Dua $1 \mathrm{ek} .4,7 \times 9=63$ \\
\hline Ölüm korkusu 2kk. 9, 2x9 = 18 & Dua $6 \mathrm{kk} .1,10 \times 10=100$ & Ahiret inanc1 $1 \mathrm{ek} .6,5 \times 7=35$ \\
\hline Namaz 2kk. 10, 1x8= 8 & Ahiret $6 \mathrm{kk} .4,7 \times 10=70$ & Dua 4ek. $8,3 \times 10=30$ \\
\hline Mezar 3kk. 10, 1x10= 10 & Kabir azab1/sorgu 7kk. 2, 9x10=90 & Din 5ek. $7,4 \times 10=40$ \\
\hline Ahiret/k1yamet $4 \mathrm{kk} .5,6 \times 10=60$ & Ürperme $8 \mathrm{kk} .7,4 \times 10=40$ & Dua 5ek. $10,1 \times 10=10$ \\
\hline Korku 4kk. $8,3 \times 8=24$ & Dini bilgi edinmek 6ek. $9,2 \times 9=18$ & Dua etmek 6ek. $10,1 \times 10=10$ \\
\hline Din 7 ek. $5,6 \times 10=60$ & Dini değerler 8ek.8, 3x10=30 & Dua 8ek. $10,1 \times 10=10$ \\
\hline Ahiret inanc1 8 ek. $7,4 \times 10=40$ & Korku $7 \mathrm{kk} .10,1 \times 6=6$ & Allah rızası 4 ek. $9,2 \times 10=20$ \\
\hline Rahmet 5ek. 9, 2x10=20 & Cami 7ek.9, 2x5= 10 & Yaşamın anlamı 1ek. 9, 2x9=18 \\
\hline Sevap ve dua 5 ek. $8,3 \times 10=30$ & & \\
\hline
\end{tabular}

TOPLUMSAL DAYANIŞMA, TAZİYE VE GELENEKSEL RİTÜELLER

Paylaşma 1kk. 3, 8x7=56

Yoksulluk 1kk. 4, 7x9=63

Birliktelik 1kk. 5, 6x8 $=48$

Nezaket 1kk. 9, 2x5=10

Hayır işleme $1 \mathrm{kk} .10,1 \mathrm{x} 8=8$

Ziyaret 2kk. 3, 8x7=56

Paylaşmak 2kk. 5, 6x10=60
Kalabalık 4kk. 1, 10x10=100

Sayg $14 k k$. 2, 9x10= 90

Aile/akraba 4kk. 4, 7x10=70

Destek 4kk. 7, 4x8=32

Yoğunluk 4kk. 9, 2x5=10

Hizmet 4kk. 10, 1x3= 3

Baş sağlığ 5 kk. $6,5 \times 10=50$
Sohbet 6kk. 5, 6x4=24

Çay 6kk. 6, 5x1=5

Yemek 6kk. 7, 4x1=4

Dayanışma 6kk 9, 2x9=18

Merhamet 6kk. 10, 1x6=6

Kültür 7kk. 4, 7x10=70

Birliktelik 7kk.5, 6x10=60 
Destek olma $3 \mathrm{kk} .4,7 \times 9=63$

Kalabalık 3kk. 5, 6x10=60

Kavurma-pilav 3kk. 7, 4x10= 40

Manevi destek 3kk. 9, 2x10= 20

Dayanışma 8kk. 3, 8x5 $=40$

Dayanışma 1ek. 3, 8x10=80

Birliktelik 1ek. 5, 6x8 $=48$

Merhamet 1ek. $7,4 \times 9=36$

Aidiyet 1ek. 8, 3x8=24

Sohbet 1ek. $10,1 \times 10=10$

Birlik beraberlik 2ek. 1, 10x10=100

Yemek 2ek. 3, 8x7= 56

Çay 2ek. $4,7 \times 5=35$

İyilik 2ek.7, 4x9=36

Sabir 2ek. 8, 3x7= 21

Akrabalar 2ek. 9, 2x8=16

İnsanlık-dostluk 2ek. 10, 1x10=10

Birlik beraberlik 6ek.5, $6 \times 10=60$

Kaynaşmak 6ek. 6, 5x9=45

Toplu yemek 6ek. 7, 4x10= 40

Paylaşım 8ek. 1, 10x10= 100

Birliktelik 8ek. 2, 9x10=90
Hatırlanmak 5kk. 7, 4x8=32

Mefta helvas1 5kk. 8, 3x5=15

Taziye yemeği $5 \mathrm{kk} .9,2 \times 6=12$

Paylaşma 6kk. 2, 9x6=54

Para desteği 8kk. 4, 7x9=63

Acıyı paylaşma 3ek. $1,10 \times 10=100$

Gelenek 3ek. 2, 9x6=54

Kaynaşma 3ek. 3, 8x5=40

Görev 3ek. 4, 7x $8=56$

Sayginlık 3ek. 5, 6x4=24

Ders almak 3ek. 6, 5x7=35

Komşuluk hakkı 3ek. 7, 4x7=28

Kişisel ilişkiler 3ek. 8, 3x9= 27

Helalleşmek 3ek. 10, 1x6=6

Baş sağllğ $\breve{1}_{1}$ ek. $1,10 \times 10=100$

Birlik beraberlik 4ek. 3, 8x9=72

Dayanışma 4ek. 4, 7x9=63

Baş sağlı̆̆ 1 ek. 2, 9x10=90

Toplanma yeri 7 ek. 3, 8x8 $=64$

Kavurma 7ek. 4, 7x1=7

Kaynaşma 8ek. 3, 8x9=72

Kalabalı 8 ek. 5, 6x10=60
Yardımlaşma 7kk. 6, 5x10=50

Acıyı paylaşma 7kk. 7, 4x10=40

Sosyallik 7kk. $8,3 \times 9=27$

Maddi destek 7kk. 9, 2x8=16

Yoksulluk 8kk. 10, 1x9=9

Sahip çıkma 4ek. 5, 6x8=48

İmece 4ek. $6,5 \times 10=50$

Acıya ortak olma 4ek. 10, 1x9=9

Vefa 5ek. 2, 9x9=81

Birliktelik 5ek. 3, 8x8=64

Dayanışma 5ek. 4, 7x10=70

Gelenek 5ek. 5, 6x6=36

Kültür 5ek. 6, 5x7=35

Acının paylaşılması $6 \mathrm{ek} .1,10 \times 10=100$

Dayanışma 6ek. 2, 9x10=90

Toplanmak 6ek. 3, 8x9=72

Paylaşmak 6ek. $4,7 \times 10=70$

Akrabalar 7ek. 6, 5x10=50

Yardımlaşma 7ek. 7, 4x10=40

Yaşam 7ek. 10, 1x1=1

İyi hissetme 8ek. 9, 2x1=2

NOT: Bilişsel kurgulardaki kısaltma ve değerlerin anlamı. İlk sayı katılımcının sırasını, yanındaki harf ise cinsiyetini ve $\mathrm{k}$ katılımcı ifadesini gösterir. Devamında ilk rakam bilişsel kurgunun sıra değerini, çarpımı yapılan iki sayı ise ilk rakam bilişsel kurgunun sıra puan değerini ikinci rakam bilişsel kurguya ait katılımcı öznel değerlendirmesini ve eşitlikten sonraki değer ise bilişsel kurgunun ağırlıklı puanını gösterir. Örneğin $(3 k k 5,7 x 5=35) 3$ katılımcının sırasını, kk veya ek katılımcının cinsiyetini (kadın katılımc1/ erkek katılımcı), 5 bilişsel kurgunun sıra değerini, 7 bilişsel kurgunun sıra puan değeri 5 bilişsel kurguya ilişkin katılımcı öznel değerlendirmesini ve 35 bilişsel kurgunun sahip olduğu ağırlıklı puanı temsil etmektedir.

Tablo 2'de Tüm katılımcıların ürettikleri bilişsel kurgular yer almaktadır. Araştırmaya katılan toplam 16 (on altı) katılımcıdan her biri 10 (on) bilişsel kurgu üretmiştir. Böylelikle Tablo 2'de 160 (yüz altmış) bilişsel kurgu yer almıştır. Bilişsel kurgular benzerlikleri açısından yani birbirleri ile ilişkileri kavramlar gruplandığında 4 (dört) bilişsel kurgu grubu/kategorisi elde edilmiştir. Tablo 2'de kabaca görüleceği üzere en fazla bilişsel kurgunun yer aldığı grup “Taziye, Toplumsal Dayanışma ve Geleneksel
Ritüeller" kurgu grubu olmuștur. Fakat her bir bilișsel kurgu grubunda yer alan kurgu miktarı o bilişsel kurgu grubunun kaba bir değerlendirmesini yapmaya imkan tanısa da o kurgu grubunun görece önem düzeyini belirlemeye yeterli değildir. Dolayısıyla araştırma kapsamında elde edilen bilişsel kurguların gruplara dağılımının katılımcılar üzerinden görece önem düzeyi incelenmiştir. İncelemeler sonucunda elde edilen bulgular Tablo 3'te yer almaktadır.

Tablo 3: Tüm Katılımcılara Ait Bilişsel Kurguların Görece Önem Düzeyi

\begin{tabular}{|c|c|c|c|c|c|c|c|c|}
\hline \multirow[t]{2}{*}{ Katılımeı } & \multicolumn{2}{|c|}{ Ölüm ve Yas } & \multicolumn{2}{|c|}{$\begin{array}{l}\text { Hüzün, Ağlama } \\
\text { ve Acı Çekme }\end{array}$} & \multicolumn{2}{|c|}{$\begin{array}{l}\text { Ölüm Korkusu, Dua } \\
\text { ve Ahiret İ́ancı }\end{array}$} & \multicolumn{2}{|c|}{$\begin{array}{l}\text { Toplumsal Dayanışma, Taziye } \\
\text { ve Geleneksel Ritüeller }\end{array}$} \\
\hline & $\mathbf{K S}$ & KP & KS & KP & KS & KP & KS & KP \\
\hline $1 \mathbf{k k}$ & 2 & 94 & 3 & 147 & - & - & 5 & 185 \\
\hline $2 \mathbf{k k}$ & 4 & 211 & 1 & 63 & 3 & 66 & 2 & 116 \\
\hline $3 \mathbf{k k}$ & 2 & 121 & 3 & 115 & 1 & 10 & 4 & 183 \\
\hline $4 \mathrm{kk}$ & 1 & 35 & 1 & 72 & 2 & 84 & 6 & 305 \\
\hline $5 \mathbf{k k}$ & 3 & 240 & 2 & 100 & 1 & 56 & 4 & 109 \\
\hline $6 \mathbf{k k}$ & 1 & 80 & 1 & 24 & 2 & 170 & 6 & 111 \\
\hline $7 \mathbf{k k}$ & 1 & 100 & 1 & 80 & 2 & 96 & 6 & 263 \\
\hline $8 \mathbf{k k}$ & 3 & 144 & 3 & 116 & 1 & 40 & 3 & 112 \\
\hline 1ek & 1 & 100 & 1 & 81 & 3 & 113 & 5 & 198 \\
\hline $2 \mathrm{ek}$ & 2 & 130 & 1 & 42 & - & - & 7 & 274 \\
\hline 3ek & - & - & 1 & 16 & - & - & 9 & 370 \\
\hline 4ek & 2 & 126 & - & - & 2 & 50 & 6 & 342 \\
\hline $5 \mathrm{ek}$ & 1 & 100 & - & - & 4 & 100 & 5 & 286 \\
\hline 6ek & - & - & 1 & 24 & 2 & 28 & 7 & 477 \\
\hline 7ek & 1 & 100 & 1 & 30 & 2 & 70 & 6 & 252 \\
\hline 8ek & 1 & 50 & 1 & 49 & 3 & 80 & 5 & 324 \\
\hline Toplam & 25 & 1631 & 21 & 959 & 28 & 963 & 86 & 3907 \\
\hline Ortalama & 65.24 & & 45.6 & & 34.3 & & 45.4 & \\
\hline
\end{tabular}

Not: KS: Bilişsel Kurgu Sayısı; KP: Bilişsel Kurgu Puanı; 1kk: Bir numaralı kadın katılımcı, 1ek, Bir numaralı erkek katılımcı

Tablo 3'te görüldüğü üzere araştırmaya katılan her bir katılımcının bilişsel kurgu gruplarında ürettiği bilişsel kurgular ve bu bilişsel kurgulara verdikleri puanlar yer almaktadır. Araştırmaya dahil edilen katılımcıların ürettikleri bilişsel kurguların ağırlıklı önem derecesini göstermek üzere, her bir bilişsel kurgu grubunda ürettikleri 
bilişsel kurgu puanlarının o grupta üretilen bilişsel kurgu sayısına bölümünden aritmetik ortalamalar elde edilmiştir. Buna göre aritmetik ortalamalar dikkate alındığında, taziye evlerine ilişkin olarak katılımcılar, görece önem sırasına göre ilk sirada "Ölüm ve Yas" kurgu grubunu önemli görmüşlerdir ( $\overline{\mathrm{x}}=65.24)$; ikinci sirada "Hüzün, Ağlama ve Acl Çekme" ( $\mathrm{x}=45.66)$ ve üçüncü sirada ise "Toplumsal Dayanışma, Taziye ve Geleneksel Ritüeller” ( $\overline{\mathrm{x}}=45.43)$ bilişsel kurgu grubunu önemli görülmüşlerdir. Ancak tablo 3 'te de görüldüğü gibi katılımcıların en fazla bilişsel kurgu ürettikleri kategori 86 kurgu ve 3907 kurgu puanı ile “Toplumsal Dayanısma, Taziye ve Geleneksel Ritüeller" olmuştur. En az kurgu üretilen kategori ise 21 kurgu ve 959 kurgu puanı ile "Hüzün, Ağlama ve Acı Çekme " bilişsel kurgu grubu olmuştur. Bu bağlamda bilişsel kurgu grupları farklı ölçütler açısından (aritmetik ortalama, toplam puan, kurgu sayısı) değerlendirmeye tabi tutulabilir. $\mathrm{Bu}$ araştırmada da değerlendirmeler bilişsel kurgu gruplarının aritmetik ortalamaları üzerinden yapılmıştır. Katılımcıların ürettikleri bilişsel kurgu gruplarının cinsiyet değişkenine göre dağılımları incelenmiş ve kadın katılımcıların ürettikleri bilişsel kurgular benzerliklerine göre gruplandırılmış olarak aşağıda Tablo 4'te yer almaktadır.

Tablo 4: Kadın Katılımcılara Ait Bilişsel Kurgular

\begin{tabular}{|c|c|c|}
\hline \multicolumn{3}{|c|}{ ÖLÜM ve YAS } \\
\hline Kayıp 1kk. 1, 10x7=70 & Ölüm 3kk. 1, 10x10= 100 & Ölüm 6kk. 3, 8x10= 80 \\
\hline Geride birakma $1 \mathrm{kk} .7,4 \times 6=24$ & Kurtuluş/son $3 \mathrm{kk} .8,3 \times 7=21$ & Ölüm 7kk. 1, 10x10= 100 \\
\hline Cenaze 2.kk. 1, 10x 5= 50 & Ayrılık/son 4kk. 6, 5x7=35 & Ölüm 8kk. 1, 10x6= 60 \\
\hline Ölüm 2kk. 2, 9x10=90 & Yas 5kk. $1,10 \times 10=100$ & Fani olma/ölümlü olma 8kk. 5, 6x9=54 \\
\hline Fani dünya $2 \mathrm{kk} .6,5 \times 10=50$ & Ölüm 5kk. 3, 8x10= 80 & Geçicilik 8kk. 8, 3x10=30 \\
\hline Geçici mevkiler 2kk. $8,3 \times 7=21$ & Yaşamın sonu $5 \mathrm{kk} .5,6 \times 10=60$ & \\
\hline \multicolumn{3}{|c|}{ HÜZÜN, AĞLAMA ve ACI CEKME } \\
\hline Hüzün 1kk. 2, 9x9=81 & Üzüntü 3kk. 3, 8x7=56 & Tefekkür/hüzün 6kk. $8,3 \times 8=24$ \\
\hline Ağlama $1 \mathrm{kk} .6,5 \mathrm{x} 9=45$ & Gözyaşı $3 \mathrm{kk} .6,5 \times 10=50$ & Ac1 $7 \mathrm{kk} \cdot 3,8 \times 10=80$ \\
\hline Karamsarlık $1 \mathrm{kk} .8,3 \times 7=21$ & Üzüntü 4kk. 3, 8x9=72 & Anma 8kk. $2,9 \times 7=63$ \\
\hline Ac1 $2 \mathrm{kk} .4,7 \mathrm{x} 9=63$ & Ac1-keder 5kk. 2, 9x10=90 & Üzüntü 8kk. $6,5 \times 7=35$ \\
\hline Mutsuzluk 3 kk. $2,9 \times 1=9$ & Kalanların acisi $5 \mathrm{kk} .10,1 \times 10=10$ & Hasret giderme $8 \mathrm{kk} .9,2 \times 9=18$ \\
\hline \multicolumn{3}{|c|}{ ÖLÜM KORKUSU, DUA VE AHIIRETE İNANCI } \\
\hline Ahiret inanc1 $2 \mathrm{kk} .7,4 \times 10=40$ & Ahiret/k1yamet 4kk. 5, 6x10=60 & Ahiret $6 \mathrm{kk} .4,7 \times 10=70$ \\
\hline Ölüm korkusu 2kk. 9, 2x9=18 & Korku 4 kk. $8,3 \times 8=24$ & Kabir azabı/sorgu 7kk. 2, 9x10=90 \\
\hline Namaz 2kk. $10,1 \mathrm{x} 8=8$ & Ahiret $5 \mathrm{kk} .4,7 \mathrm{x} 8=56$ & Korku $7 \mathrm{kk} .10,1 \times 6=6$ \\
\hline Mezar $3 \mathrm{kk} .10,1 \times 10=10$ & Dua 6 kk. $1,10 \times 10=100$ & Ürperme 8kk. $7,4 \times 10=40$ \\
\hline \multicolumn{3}{|c|}{$\begin{array}{c}\text { TOPLUMSAL DAYANIŞMA, TAZIYE VE GELENEKSEL RİTÜELLER } \\
\end{array}$} \\
\hline Paylaşma $1 \mathrm{kk} .3,8 \times 7=56$ & Sayg1 4kk. $2,9 \times 10=90$ & Yemek 6kk. 7, 4x1=4 \\
\hline Yoksulluk 1 kk. $4,7 \times 9=63$ & Aile/akraba $4 \mathrm{kk} .4,7 \times 10=70$ & Dayanışma $6 \mathrm{kk} 9,2 \times 9=18$ \\
\hline Birliktelik 1kk. 5, 6x8=48 & Destek 4 kk. $7,4 \times 8=32$ & Merhamet $6 \mathrm{kk} .10,1 \times 6=6$ \\
\hline Nezaket 1 kk. $9,2 \times 5=10$ & Yoğunluk 4kk. 9, 2x5=10 & Kültür 7kk. 4, 7x10=70 \\
\hline Hayır işleme $1 \mathrm{kk} .10,1 \mathrm{x} 8=8$ & Hizmet $4 \mathrm{kk} .10,1 \times 3=3$ & Birliktelik 7kk.5, 6x10= 60 \\
\hline Ziyaret $2 \mathrm{kk} .3,8 \times 7=56$ & Baş sağ $\operatorname{lŏ}_{1} 5 \mathrm{kk} .6,5 \times 10=50$ & Yardımlaşma 7kk. $6,5 \times 10=50$ \\
\hline Paylaşmak 2kk. 5, $6 \times 10=60$ & Hatırlanmak 5kk. $7,4 \times 8=32$ & Acıyı paylaşma $7 \mathrm{kk} .7,4 \times 10=40$ \\
\hline Destek olma $3 \mathrm{kk} .4,7 \times 9=63$ & Mefta helvasi $5 \mathrm{kk} .8,3 \times 5=15$ & Sosyallik $7 \mathrm{kk} .8,3 \times 9=27$ \\
\hline Kalabalık 3kk. 5, 6x10=60 & Taziye yemeği $5 \mathrm{kk} .9,2 \times 6=12$ & Maddi destek 7kk. 9, 2x8=16 \\
\hline Kavurma-pilav 3kk. 7, 4x10=40 & Paylaşma $6 \mathrm{kk} .2,9 \times 6=54$ & Dayanışma 8kk. 3, 8x5=40 \\
\hline Manevi destek 3kk. 9, 2x10=20 & Sohbet $6 \mathrm{kk} .5,6 \mathrm{x} 4=24$ & Para desteği 8kk. $4,7 \times 9=63$ \\
\hline Kalabalık 4kk. 1, 10x10=100 & Çay $6 \mathrm{kk} .6,5 \times 1=5$ & Yoksulluk 8kk. 10, 1x9=9 \\
\hline
\end{tabular}

NOT: Bilişsel kurgulardaki kısaltma ve değerlerin anlamı. İlk sayı katılımıının sırasını, yanındaki harf ise cinsiyetini ve k katılımeı ifadesini gösterir. Devamında ilk rakam bilişsel kurgunun sıra değerini, çarpımı yapılan iki sayı ise ilk rakam bilişsel kurgunun sıra puan değerini ikinci rakam bilişsel kurguya ait katılımcı öznel değerlendirmesini ve eşitlikten sonraki değer ise bilişsel kurgunun ağılıklı puanını gösterir. Örneğin $(3 k k 5$, $7 x 5=35) 3$ katılımcının sırasını, kk katılımcının cinsiyetini (kadın katılımcı), 5 bilişsel kurgunun sıra değerini, 7 bilişsel kurgunun sıra puan değeri 5 bilişsel kurguya ilişkin katılımcı öznel değerlendirmesini ve 35 bilişsel kurgunun sahip olduğu ağırlıklı puanı temsil etmektedir.

Araştırmada 16 katılımcı yer almıştır. Bu katılımcılardan 8'i erkek ve 8'i de kadındır. Tablo 4'de görüldüğü üzere araştırmaya katılan kadın katılımcıların ürettikleri bilişsel kurgular yer almaktadır. Tablo 4'de görüldüğü üzere 8 (sekiz) kadın katılımcı 80 (seksen) bilişsel kurgu üretmiştir. $\mathrm{Bu}$ bilişsel kurgular benzerlikleri açısından gruplandırılmıştır. Oluşturulan her bilişsel kurgu grubu, o bilişsel kurgu grubunda yer alan kurguları kapsayacak ve bilişsel kurgu grubunun özelliğini yansıtacak biçimde seslendirilmiştir.

Araştırmaya katılan kadın katılımcıların ürettikleri bilişsel kurgulardan oluşturulan gruplarda yapılan seslendirmeye göre dört bilişsel kurgu grubu ortaya çıkmıştır. Tablo 4'de yer alış sırasına göre araştırmaya katılan kadın katılımcılar "Ölüm ve Yas", "Hüzün, Ağlama ve Acl Çekme", "Ölüm Korkusu, Dua ve Ahiret Inancl”, "Toplumsal Dayanışma, Taziye ve Geleneksel Ritüeller" bilişsel kurgu grupları olmuşlardır. Ancak her bir bilişsel kurgu grubunda yer alan kurgu miktarı o bilişsel kurgu grubunun kaba bir değerlendirmesini yapmaya imkan tanısa da o kurgu grubunun görece önem düzeyini belirlemeye yeterli değildir. $\mathrm{Bu}$ nedenle kadın katılımcılara ait bilişsel kurguların görece önem düzeyi aşağıda tablo 5'te yer almaktadir. 
Tablo 5: Kadın katılımcılara ait bilişsel kurguların görece önem düzeyi

\begin{tabular}{|c|c|c|c|c|c|c|c|c|}
\hline \multirow[t]{2}{*}{ Katılımeı } & \multicolumn{2}{|c|}{ Ölüm ve Yas } & \multicolumn{2}{|c|}{$\begin{array}{l}\text { Hüzün, Ağlama } \\
\text { ve Acı Çekme }\end{array}$} & \multicolumn{2}{|c|}{$\begin{array}{l}\text { Ölüm Korkusu, Dua } \\
\text { ve Ahiret İnancı }\end{array}$} & \multicolumn{2}{|c|}{$\begin{array}{l}\text { Toplumsal Dayanışma, } \\
\text { Taziye ve Geleneksel Ritüeller }\end{array}$} \\
\hline & KS & KP & KS & KP & KS & KP & KS & KP \\
\hline$\overline{1 k k}$ & 2 & 94 & 3 & 147 & - & - & 5 & 185 \\
\hline $2 \mathbf{k k}$ & 4 & 211 & 1 & 63 & 3 & 66 & 2 & 116 \\
\hline $3 \mathbf{k} \mathbf{k}$ & 2 & 121 & 3 & 115 & 1 & 10 & 4 & 183 \\
\hline $4 \mathbf{k k}$ & 1 & 35 & 1 & 72 & 2 & 84 & 6 & 305 \\
\hline $5 \mathbf{k k}$ & 3 & 240 & 2 & 100 & 1 & 56 & 4 & 109 \\
\hline 6kk & 1 & 80 & 1 & 24 & 2 & 170 & 6 & 111 \\
\hline $7 \mathbf{k k}$ & 1 & 100 & 1 & 80 & 2 & 96 & 6 & 263 \\
\hline $8 \mathbf{k k}$ & 3 & 144 & 3 & 116 & 1 & 40 & 3 & 112 \\
\hline Toplam & 17 & 1025 & 15 & 717 & 12 & 522 & 36 & 1384 \\
\hline Ortalama & 60.29 & & 47.8 & & 43.5 & & 38.4 & \\
\hline
\end{tabular}

Not: KS: Bilişsel kurgu sayısı; KP: Bilişsel kurgu puanı; 1kk: Bir numaralı kadın katılımcı

Kadın katılımcıların ürettikleri bilișsel kurguların görece önem düzeyleri belirlenerek, her bir bilişsel kurgu grubunun kadın katılımcıların ürettiği kurgu grupları içindeki ağırlıklı yeri belirlenmiştir. Tablo 5'te görüldüğü gibi araştırmaya katılan kadın katılımcıların bilişsel kurgu gruplarında ürettiği bilişsel kurgular ve bu bilişsel kurgulara verdikleri puanlar yer almaktadır. Ürettikleri bilişsel kurguların ağırlıklı önem derecesini göstermek üzere, her bir bilişsel kurgu grubunda ürettikleri bilişsel kurgu puanlarının o grupta üretilen bilişsel kurgu sayısına bölümünden elde edilen aritmetik ortalamalar elde edilmiştir. Buna göre görece önem sırası taziye evlerine ilișkin kadın katılımcılar, ilk sırada "Ölüm ve Yas" adlı bilişsel kurgu grubunu önemli görmüşlerdir ( $\bar{x}=60.29)$.
İkinci sırada “Hüzün, Ağlama ve Acl Çekme”, ( $\bar{x}=47.8)$ ve üçüncü sirada ise "Ölüm Korkusu, Dua ve Ahiret Inancl” ( $\overline{\mathrm{x}}=43.5)$. adlı bilişsel kurgu grubunu önemli görülmüşlerdir. Araştırmaya katılan kadın katılımcıların en fazla bilişsel kurgu ürettikleri bilişsel kurgu grubu, 36 kurgu say1s1 ve 1384 kurgu puanı ile "Toplumsal Dayanışma, Taziye ve Geleneksel Ritüeller” bilişsel kurgu grubu olurken; en az kurgu ürettikleri bilişsel kurgu grubu ise 12 kurgu sayıs1 ve 522 kurgu puanı ile "Ölüm Korkusu, Dua ve Ahiret İnancl" bilişsel kurgu grubu olmuştur. Fakat bu çalışmada aritmetik ortalamalar dikkate alınarak görece önem sırası belirlenmiştir. Erkek katılımcılara ait bilişsel kurgular ise aşağıda Tablo 6'da yer almaktadır.

Tablo 6: Erkek Katılımcılara Ait Bilişsel Kurgular

\begin{tabular}{|c|c|c|}
\hline \multicolumn{3}{|c|}{ ÖLÜM ve YAS } \\
\hline Ölüm 1ek. 1, 10x10= 100 & Ölüm 4ek. 2, 9x10=90 & Ölüm 7ek. 1, 10x10= 100 \\
\hline Ölüm 2ek. 2, 9x10=90 & Yas tutma 4 ek. $7,4 \times 9=36$ & Ölüm 8ek. $6,5 \times 10=50$ \\
\hline Hayatın anlamsızlığı 2ek. $6,5 \mathrm{x} 8=40$ & Ölüm 5ek. 1, 10x10=100 & \\
\hline \multicolumn{3}{|c|}{ HÜZÜN, AĞLAMA ve ACI ÇEKME } \\
\hline Hüzün 1ek. 2, 9x9= 81 & Anıların canlanmasi 3 ek. $9,2 \times 8=16$ & Acısını hatırlama 7 ek. $8,3 \times 10=30$ \\
\hline Üzüntüler 2ek. 5, 6x7= 42 & Üzüntüleri dinlemek $6 \mathrm{ek} .8,3 \mathrm{x} 8=24$ & Üzüntü 8ek. 4, 7x7=49 \\
\hline \multicolumn{3}{|c|}{ ÖLÜM KORKUSU, DUA VE AHİRETE İNANCI } \\
\hline Dua 1ek. $4,7 \times 9=63$ & Sevap ve dua 5 ek. $8,3 \times 10=30$ & Din 7ek. $5,6 \times 10=60$ \\
\hline Ahiret inanc1 1 ek. $6,5 \times 7=35$ & Rahmet 5ek. $9,2 \times 10=20$ & Cami 7ek.9, 2x5=10 \\
\hline Yaşamın anlamı 1ek. 9, 2x9=18 & Dua 5 ek. $10,1 \times 10=10$ & Ahiret inanc1 8 ek. $7,4 \times 10=40$ \\
\hline Dua 4 ek. $8,3 \times 10=30$ & Dini bilgi edinmek 6ek. $9,2 \times 9=18$ & Dini değerler $8 \mathrm{ek} .8,3 \times 10=30$ \\
\hline Allah rızas1 4ek. $9,2 \times 10=20$ & Dua etmek $6 \mathrm{ek} .10,1 \times 10=10$ & Dua 8 ek. $10,1 \times 10=10$ \\
\hline Din 5 ek. $7,4 \times 10=40$ & & \\
\hline \multicolumn{3}{|c|}{$\begin{array}{l}\text { TOPLUMSAL DAYANIŞMA, TAZIYYE VE GELENEKSEL RİTÜELLER } \\
\end{array}$} \\
\hline Dayanışma 1ek. $3,8 \times 10=80$ & Saygınlık 3ek. $5,6 \times 4=24$ & Acının paylaşılması $6 \mathrm{ek} .1,10 \times 10=100$ \\
\hline Birliktelik 1ek. 5, $6 \times 8=48$ & Ders almak 3 ek. $6,5 \times 7=35$ & Dayanışma 6ek. $2,9 \times 10=90$ \\
\hline Merhamet 1 ek. $7,4 \times 9=36$ & Komşuluk hakkı $3 \mathrm{ek} .7,4 \times 7=28$ & Toplanmak 6ek. 3, 8x9=72 \\
\hline Aidiyet 1 ek. $8,3 \times 8=24$ & Kişisel ilişkiler 3 ek. $8,3 \times 9=27$ & Paylaşmak 6ek. $4,7 \times 10=70$ \\
\hline Sohbet 1 ek. $10,1 \times 10=10$ & Helalleşmek 3 ek. 10, 1x6= 6 & Birlik beraberlik 6 ek.5, $6 \times 10=60$ \\
\hline Birlik beraberlik 2ek. $1,10 \times 10=100$ & Baş sağlığ 4 ek. $1,10 \times 10=100$ & Kaynaşmak 6ek. $6,5 \times 9=45$ \\
\hline Yemek 2ek. 3, 8x7=56 & Birlik beraberlik 4ek. $3,8 \times 9=72$ & Toplu yemek $6 \mathrm{ek} .7,4 \times 10=40$ \\
\hline Çay 2ek. $4,7 \times 5=35$ & Dayanışma 4ek. 4, 7x9=63 & Baş sağlığ 7 ek. $2,9 \times 10=90$ \\
\hline İyilik 2ek.7, 4x9= 36 & Sahip çıkma 4ek. 5, 6x8 $=48$ & Toplanma yeri 7 ek. $3,8 \times 8=64$ \\
\hline Sabır 2ek. $8,3 \times 7=21$ & İmece 4 ek. $6,5 \times 10=50$ & Kavurma 7 ek. $4,7 \times 1=7$ \\
\hline Akrabalar 2ek. 9, 2x8=16 & Acıya ortak olma 4 ek. $10,1 \times 9=9$ & Akrabalar 7ek. $6,5 \times 10=50$ \\
\hline İnsanlık-dostluk 2ek. 10, 1x10=10 & Vefa 5 ek. $2,9 \times 9=81$ & Yardımlaşma 7ek. 7, 4x10=40 \\
\hline Acıy1 paylaşma 3 ek. $1,10 \times 10=100$ & Birliktelik 5ek. 3, 8x8=64 & Yaşam 7ek. 10, 1xl=1 \\
\hline Gelenek 3ek. $2,9 \times 6=54$ & Dayanışma 5ek. $4,7 \times 10=70$ & Paylaşım 8ek. $1,10 \times 10=100$ \\
\hline Kaynaşma 3 ek. $3,8 \times 5=40$ & Gelenek 5ek. 5, 6x6=36 & Birliktelik 8ek. 2, 9x10=90 \\
\hline Görev 3ek. 4, 7x8=56 & Kültür 5ek. 6, 5x7= 35 & Kaynaşma 8ek. $3,8 \times 9=72$ \\
\hline Kalabalık 8ek. $5,6 \times 10=60$ & İyi hissetme $8 \mathrm{ek} .9,2 \times 1=2$ & \\
\hline
\end{tabular}

NOT: Bilișsel kurgulardaki kısaltma ve değerlerin anlamı. İlk sayı katılımcının sırasını, yanındaki harf ise cinsiyetini ve k katılımcı ifadesini gösterir. Devamında ilk rakam bilişsel kurgunun sıra değerini, çarpımı yapılan iki sayı ise ilk rakam 
bilişsel kurgunun sıra puan değerini ikinci rakam bilişsel kurguya ait katılımcı öznel değerlendirmesini ve eşitlikten sonraki değer ise bilişsel kurgunun ağırlıklı puanını gösterir. Örneğin (2ek. 4, 7x5=35)2 katılımcının sırasını, ek katılımcının cinsiyetini (erkek katılımcı), 4 bilişsel kurgunun sıra değerini, 7 bilişsel kurgunun sıra puan değeri 5 bilişsel kurguya ilişkin katılımcı öznel değerlendirmesini ve $\mathbf{3 5}$ bilişsel kurgunun sahip olduğu ağırlıklı puanı temsil etmektedir.

Tablo 6'da araştırmaya katılan erkek katılımcıların ürettikleri bilişsel kurgular yer almaktadır. Tablo 6'da görüldüğü üzere, araştırmaya katılan 8 (sekiz) erkek katılımcı 80 (seksen) bilişsel kurgu üretmiştir. Bu bilişsel kurgular benzerlikleri açısından gruplandırılmıştır. Oluşturulan her bilişsel kurgu grubu, o bilişsel kurgu grubunda yer alan kurguları kapsayacak ve bilişsel kurgu grubunun özelliğini yansıtacak biçimde seslendirilmiş ve benzerlikleri dikkate alındığında dört bilişsel kurgu grubu altında toplanmıştır. Tablo 6'da görüldüğü gibi bu bilişsel kurgu grupları tabloda yer alma sırasına göre "Ölüm ve
Yas”, “Hüzün, Ağlama ve Acı Çekme”, “Ölüm Korkusu, Dua ve Ahiret Inancl”, "Toplumsal Dayanışma, Taziye ve Geleneksel Ritüeller" bilişsel kurgu gruplarıdır. Ancak her bir bilişsel kurgu grubunda yer alan kurgu miktarı o bilişsel kurgu grubunun kaba bir değerlendirmesini yapmaya imkân tanısa da o kurgu grubunun görece önem düzeyini belirlemeye yeterli değildir. Bundan dolayı erkek katılımcıların ürettikleri bilişsel kurguların görece önem düzeyleri belirten veriler aşağıda Tablo 7'de yer almaktadır.

Tablo 7: Erkek Katılımcılara Ait Bilişsel Kurguların Görece Önem Düzeyi

\begin{tabular}{lllllllll}
\hline \multirow{2}{*}{ Katılımcı } & \multicolumn{2}{l}{$\begin{array}{l}\text { Ölüm ve } \\
\text { Yas }\end{array}$} & \multicolumn{2}{l}{$\begin{array}{l}\text { Hüzün, Ağlama } \\
\text { ve Acı Çekme }\end{array}$} & \multicolumn{2}{l}{$\begin{array}{l}\text { Ölüm Korkusu, Dua } \\
\text { ve Ahiret İnanci }\end{array}$} & \multicolumn{2}{l}{$\begin{array}{l}\text { Toplumsal Dayanışma, } \\
\text { Taziye ve Geleneksel Ritüeller }\end{array}$} \\
\cline { 2 - 10 } & KS & KP & KS & KP & KS & KP & KS & KP \\
\hline 1ek & 1 & 100 & 1 & 81 & 3 & 113 & 5 & 198 \\
2ek & 2 & 130 & 1 & 42 & - & - & 7 & 274 \\
3ek & - & - & 1 & 16 & - & - & 9 & 370 \\
4ek & 2 & 126 & - & - & 2 & 50 & 6 & 342 \\
5ek & 1 & 100 & - & - & 4 & 100 & 5 & 286 \\
6ek & - & - & 1 & 24 & 2 & 28 & 7 & 477 \\
7ek & 1 & 100 & 1 & 30 & 2 & 70 & 6 & 252 \\
8ek & 1 & 50 & 1 & 49 & 3 & 80 & 5 & 324 \\
\hline Toplam & $\mathbf{8}$ & $\mathbf{6 0 6}$ & $\mathbf{6}$ & $\mathbf{2 4 2}$ & $\mathbf{1 6}$ & $\mathbf{4 4 1}$ & $\mathbf{5 0}$ & $\mathbf{2 5 2 3}$ \\
\hline Ortalama & $\mathbf{7 5 . 7 5}$ & $\mathbf{4 0 . 3 3}$ & $\mathbf{2 7 . 5 6}$ & $\mathbf{5 0 . 4 6}$ \\
\hline
\end{tabular}

Not: KS: Bilişsel kurgu sayısı; KP: Bilişsel kurgu puanı; 1ek: Bir numaralı erkek katılımcı

Tablo 7'de görüldüğü üzere araştırmaya katılan erkek katılımcıların bilişsel kurgu gruplarında ürettiği bilişsel kurgular ve bu bilişsel kurgulara verdikleri puanlar yer almaktadır. Araştırmaya katılan erkek katılımcıların ürettikleri bilişsel kurguların ağırlıklı önem derecesini göstermek üzere her bir bilişsel kurgu grubunda ürettikleri bilişsel kurgu puanlarının o grupta üretilen bilişsel kurgu sayısına bölümünden elde edilen aritmetik ortalamalar elde edilmiştir. Buna göre aritmetik ortalamalar dikkate alındığında görece önem sırası taziye evlerine ilişkin erkek katılımcıların, ilk sırada "Ölüm ve Yas" bilişsel kurgu grubunu önemli görmüşlerdir $(\overline{\mathrm{x}}=75.75)$. İkinci sırada "Toplumsal Dayanışma, Taziye ve Geleneksel Ritüeller" ( $\overline{\mathrm{x}}=50.46)$ ve üçüncü sırada ise "Hüzün, A Aglama ve Acı
Çekme" ( $\bar{x}=40.33)$ adlı bilişsel kurgu gruplarını önemli görmüşlerdir. Araştırmaya katılan erkek öğretmenlerin en fazla bilişsel kurgu ürettikleri bilişsel kurgu grubu, 50 kurgu ve 2523 kurgu puanı ile "Toplumsal Dayanışma, Taziye ve Geleneksel Ritüeller" bilişsel kurgu grubu olmuştur. En az kurgu üretilen bilişsel kurgu grubu ise 6 kurgu ve 242 kurgu puanı ile "Hüzün, Ağlama ve $\mathrm{Acl}$ Çekme” bilişsel kurgu grubu olmuştur.

Araştırmaya katılan bütün kadın ve erkek katılımcıların ürettikleri bilişsel kurgular cinsiyet değişkeni üzerinden görece en çok önemli görülenden en az önemli görülene ilişkin bilişsel kurgu grupları aşağıda Tablo 8'de yer almaktadir.

Tablo 8: Cinsiyet Üzerinden Katılımcıların Bilişsel Kurgularına Ait Karşılaştırma

\begin{tabular}{|c|c|c|c|c|c|c|c|c|}
\hline \multirow{2}{*}{$\begin{array}{l}\text { Kurgu } \\
\text { Önem } \\
\text { Sirası }\end{array}$} & \multicolumn{4}{|c|}{ Kadın } & \multicolumn{4}{|l|}{ Erkek } \\
\hline & Kurgu Grubu & $\overline{\mathbf{x}}$ & $\mathbf{K S}$ & KP & Kurgu Grubu & $\overline{\mathbf{x}}$ & $\mathbf{K S}$ & KP \\
\hline & 1- Ölüm ve Yas & 60.29 & 17 & 1025 & 1- Ölüm ve Yas & 75.75 & 8 & 606 \\
\hline $\begin{array}{l}\text { En } \\
\text { Coktan }\end{array}$ & $\begin{array}{l}\text { 2- Hüzün, Ağlama ve Ac1 } \\
\text { Cekme }\end{array}$ & 47.8 & 15 & 717 & $\begin{array}{l}\text { 2- Toplumsal Dayanışma, } \\
\text { Taziye ve Geleneksel Ritüeller }\end{array}$ & 50.46 & 50 & 2523 \\
\hline $\begin{array}{l}\text { en aza } \\
\text { göre }\end{array}$ & $\begin{array}{l}\text { 3- Ölüm Korkusu, Dua ve } \\
\text { Ahiret İnanc1 }\end{array}$ & 43.5 & 12 & 522 & 3- Hüzün, Ağlama ve Acı Çekme & 40.33 & 6 & 242 \\
\hline $\begin{array}{l}\text { önem } \\
\text { sırası }\end{array}$ & $\begin{array}{l}\text { 4- Toplumsal Dayanışma, } \\
\text { Taziye ve Geleneksel } \\
\text { Ritüeller }\end{array}$ & 38.44 & 36 & 1384 & $\begin{array}{l}\text { 4- Ölüm Korkusu, Dua ve Ahiret } \\
\text { İnancı }\end{array}$ & 27.56 & 16 & 441 \\
\hline
\end{tabular}

Not: $\overline{\mathbf{x}}$ : Ortalama; KS: Bilişsel kurgu sayısı; KP: Bilişsel kurgu puanı

Katılımcılar, araştırmanın yöntemine uygun olarak ürettikleri her bir bilișsel kurguya görece onlu (10) derecelendirme skalası üzerinden puanlama yapmışlardır. Bunun yanı sıra çalışmanın dayandığı Gömülü Kuram (Grounded Theory) açısından bilişsel kurgunun üretilme sırasına bağlı olarak da belli bir puanlamaya tabi tutulmuş olmasından dolayı, kurgu gruplarında üretilen kurgu sayısının azlığına rağmen, üretilen puanın yüksekliği söz konusu kurguların katılımcılar tarafindan diğer kurgulardan görece daha önemli görüldükleri biçiminde açıklanabilir. 
$\mathrm{Bu}$ bağlamda Tablo 8 incelendiğinde, araştırmaya katılan kadın ve erkek katılımcıların kurgu grupları kısmi farklılıklar göstermektedir. Kadın ve erkek katılımcılar için aritmetik ortalamalar dikkate alındığında ilk grup değişmemektedir. Fakat ikinci, üçüncü ve dördüncü sırada yer alan bilişsel kurgu grupları farklılaşmaktadır. Buna göre kadın katılımcılar, kurgu gruplarının aritmetik ortalamaları bağlamında görece "Hüzün, Ağlama ve Acı Çekme” kurgu grubunu ikinci sırada önemli görürlerken; erkek katılımcılar "Toplumsal Dayanışma, Taziye ve Geleneksel Ritüeller" kurgu grubunu ikinci sırada önemli görmüşlerdir. Kadın katılımcılar aritmetik ortalamalar açısından görece önemli gördükleri ilk üç kurgu grubu sirasiyla "Ölüm ve Yas", "Hüzün, Ağlama ve Acr Çekme" ve "Ölüm Korkusu, Dua ve Ahiret Inancl" kurgu grupları oluşturmaktadır. Erkek katılımcılar için ise aritmetik ortalamalar açısından görece önemli gördükleri ilk üç kurgu grubu sırasıyla "Ölüm ve Yas", "Toplumsal Dayanışma, Taziye ve Geleneksel Ritüeller" ve "Hüzün, Ağlama ve Acı Çekme” kurgu grupları oluşturmaktadır. Kadın katılımcıların görece en az önemli gördükleri kurgu grubu son sirada yer alan "Toplumsal Dayanışma, Taziye ve Geleneksel Ritüeller" iken erkek katılımcıların aritmetik ortalamalar açısından görece en az önemli gördükleri kurgu grubu ise son sırada yer alan "Ölüm Korkusu, Dua ve Ahiret İnancl" bilişsel kurgu grubu olmuştur.

\section{Sonuç ve Tartışma}

Taziye evlerine ilişkin katılımcıların bilişsel kurgularının tespit edilmesi ve cinsiyet değişkeni bağlamında karşılaştırılmasına ilişkin yürütülen bu çalışmada repertory grid görüşme tekniğine dayalı olarak veriler toplanmıştır. Belirtilen bu görüşme tekniğinde ilk olarak hangi konudaki bilişsel kurguların açığa çıkartılacağına ve bu amaçla kişilerin sahip olduğu hangi bilişsel kurguların belirleneceğine karar verilir. $\mathrm{Bu}$ araştırmada Van ve Batman illerinde ikamet etmekte olan ve bulunduğu yerleşkede taziye evi bulunan katılımcıların taziye evlerine ilişkin bilişsel kurguları belirlenmeye çalışılmıştır.

Araştırmaya katılan 16 (onaltı) katılımcı birlikte toplam 160 (yüzaltmış) bilişsel kurgu üretmiştir. Bu bilişsel kurgular benzerliklerine göre gruplandırılmış ve o grupta yer alan bilişsel kurguların bilgisine göre o bilişsel kurgu grubu seslendirilmiştir. Buna göre Ölüm ve Yas, Hüzün- Ağlama ve Acı Çekme, Ölüm Korkusu- Dua ve Ahiret İnancı, Toplumsal Dayanışma- Taziye ve Geleneksel Ritüeller olmak üzere toplam dört bilişsel kurgu grubu oluşturulmuştur. Bu kurgu gruplarına katkı sunan her bir katılımcının katkı oranının belirlendiği ve kurgu grubunun diğer kurgu grubuna oranla önem derecesinin gösterildiği analizler yapılmış ve bu analizlerin sonucunda kurgu gruplarının görece önem sırası oluşturulmuştur. Araştırmaya katılım gösteren katılımcıların ürettikleri bilişsel kurgu gruplarının görece önem sırası ise şöyle oluşmuştur: 1. sirada Ölüm ve Yas $(\overline{\mathrm{x}}=65.24)$; 2. sirada "Hüzün, Ağlama ve Acl Çekme” ( $\overline{\mathrm{x}}=45.66)$; 3. sırada "Toplumsal Dayanışma, Taziye ve Geleneksel Ritüeller" ( $\overline{\mathrm{x}}=45.43$ ) ve 4. sirada ise "Ölüm Korkusu, Dua ve Ahiret İnancı" ( $\overline{\mathrm{x}}=34.39)$ bilişsel kurgu grubu yer almaktadır. Bu bulguya dayalı olarak genel olarak katılımcıların taziye evlerine ilişkin öncelikle yas ve ölüm bilişsel kurgusunda birliktelik sağladıkları görülmektedir. Yas ve ölüm gibi acı bir durumun etrafinda kenetlenmenin ve acının paylaşılmasının önem taşıdığına ilişkin bir algıya sahip oldukları sonucuna varılabilir. Nitekim Albayrak ve Arıcı, (2007) yaptıkları çalışmada Türkiye'de acıların paylaşıldığı, küskünlerin barıştığı, sosyal ilişkilerin güçlendiği bir gelenek olan taziyenin, toplumsal bütünleşmeyi sağlayan oldukça önemli bir öge durumunda olduğu ifade etmektedirler. Dolayısıyla taziye sahibi veya sahiplerinin kendilerine destek olmak ve acılarını paylaşmak için gelenlere içlerini dökmeleri ve duygularını paylaşmalarının psikolojik açıdan iyi gelen bir durum olduğu söylenebilir. Bu bağlamda Ataman ve Barış (2019) yaptıkları çalışmada da yaslı bireylerin başkaları ile konuşarak duygularını paylaşmalarının, onların zihinlerinde acılarının işlenmesini sağladığını ve bu durum da onların acılarıyla başa çıkmalarında başarılı olmalarını kolaylaştırdığını ifade etmektedirler.

Katılımcılar, araştırmanın yöntemine uygun olarak ürettikleri her bir bilişsel kurguya görece onlu (10) derecelendirme skalası üzerinden puanlama yapmışlardır. Bunun yanı sıra çalışmanın dayandığı Gömülü Kuram (Grounded Theory) açısından (Morrison, 1990) bilişsel kurgunun üretilme sırasına bağlı olarak üretilen her kurgu belli bir puanlamaya tabi tutulmuştur. Dolayısıyla kurgu gruplarında üretilen kurgu sayısının azlığına rağmen, üretilen puanın yüksekliği söz konusu kurguların katılımcılar tarafından diğer kurgulardan görece daha önemli görüldükleri biçiminde açıklanabilir. Bu bağlamda cinsiyet değişkeni dikkate alındığında araştırmaya katılan kadın ve erkek katılımcıların kurgu grupları kısmi farklılıklar göstermektedir. Kadın ve erkek katılımcılar için aritmetik ortalamalar dikkate alındığında cinsiyet değişkenine göre ilk bilişsel kurgu grubu değişmemektedir. Fakat ikinci, üçüncü ve dördüncü sırada yer alan bilişsel kurgu grupları farklılaşmaktadır. Buna göre kadın katılımcılar, kurgu gruplarının aritmetik ortalamaları bağlamında görece "Hüzün, Ağlama ve Acı Çekme” kurgu grubunu ikinci sırada önemli görürlerken; erkek katılımcılar "Toplumsal Dayanışma, Taziye ve Geleneksel Ritüeller" kurgu grubunu ikinci sırada önemli görmüşlerdir. Kadın katılımcılar aritmetik ortalamalar açısından görece önemli gördükleri ilk üç kurgu grubu sirasıyla "Ölüm ve Yas", "Hüzün, Ağlama ve Acr Çekme” ve "Ölüm Korkusu, Dua ve Ahiret İnancl" kurgu grupları oluşturmaktadır. Erkek katılımcılar için ise aritmetik ortalamalar açısından görece önemli gördükleri ilk üç kurgu grubu sirasıyla "Ölüm ve Yas", "Toplumsal Dayanışma, Taziye ve Geleneksel Ritüeller" ve "Hüzün, Ağlama ve Acı Çekme” kurgu grupları oluşturmaktadır. Kadın katılımcıların görece en az önemli gördükleri kurgu grubu son sirada yer alan "Toplumsal Dayanışma, Taziye ve Geleneksel Ritüeller", iken erkek katılımcıların aritmetik ortalamalar açısından görece en az önemli gördükleri kurgu grubu ise son sirada yer alan "Ölüm Korkusu, Dua ve Ahiret İnancı" bilişsel kurgu grubu olmuştur. Buradan hareketle kadın ve erkek katılımcıların taziye evlerine ilişkin ilk bilişsel kurgu sıralamaları aynı iken kadınların taziye evlerine ilişkin 2. sırada görece "Hüzün, Ağlama ve Acı Çekme" kurgu grubunu; erkek katılımcılar ise "Toplumsal Dayanışma, Taziye ve Geleneksel Ritüeller" kurgu grubunu önemli görmüşlerdir. $\mathrm{Bu}$ bağlamda kadınların, yaşanan kaybın ardından duygusal yapıları bağlamında hüzün ve ağlama odaklı bir duygusal destekli yas sürecini öncelerken, 
erkeklerin ise daha çok yas sürecinde yürütülmesi gereken faaliyetler ve geleneksel dayanışma odaklı bir taziye süreci içinde yer aldıkları söylenebilir. Nitekim Parin, Bilgili ve Menak (2012) yaptıkları çalışmada geleneksel taziye ritüelinin kadınlar ve erkekler tarafından farklı şekillerde temsil edildiği vurgulanmaktadır. Kadınların daha çok ağlayan, ağıt yakan duygusal bir cephede, erkeklerin ise daha çok metanetli olmaya çalışan bir davranış dizisiyle kendilerini gösterdikleri belirtilmektedir. Benzer bir şekilde Coşkun ve Kayserili (2019) tarafından yapılan çalışmada, erkeklerden farklı olarak, kadınların taziye evlerinin dışında kaldıkları ve gelen misafirlerin kadınlar tarafından daha çok ev ortamında ağırlandıkları tespit edilmiştir. YılmazÇıldam (2020) Siirt ilinde yaptığı saha çalışmasında, kadınların taziye ritüellerinin erkeklerinkine göre farklılık gösterdiğini bulmuştur. Ayrıca çalışmada, kadınların daha çok taziye evlerinin dışında kaldıkları ve taziyeye ilişkin görevleri erkeklerden farklı bir şekilde yerine getirdikleri ortaya çıkmıştır. Balık (2019) yaptığı çalışmada, erkekler taziye evini yasın yaşandığı yer olarak tanımlarken, kadınlar ise daha çok teselli evi olarak tanımlamışlar. Bu sonuçlar, erkeklerin ve kadınların taziye evlerine ilişkin kurgularının farklı olduğunu göstermektedir.

Sonuç olarak taziye evlerine ilişkin öncelikli bilişsel kurgular incelendiğinde;

- Taziye evlerinde, taziye sahibinin yasını sağlıklı yaşaması ve atlatmasında toplumsal destek sağlandığı görülmüştür.

- Kadınların taziye evlerine ilişkin bilişsel kurgularında ölüm ve yas olgusunun ilk sıra yer aldığı yani taziye sahibinin hemen yanında yer alma, yasına ortak olma ve ikinci sırada ise hüzün, ağlama ve acı çekmenin yani duygusal yaşantıların ve paylaşımların önem taşıdığı görülmüştür.

- Erkeklerin taziye evlerine ilişkin bilişsel kurgularında ise ölüm ve yas olgusunun ilk sırada yer aldığ 1 yani taziye sahibinin hemen yanında yer alma, defin sürecinde bulunma, yasına ortak olma ve ikinci sırada ise toplumsal dayanışma, taziye süreci ve gelenekler bağlamında metanetli oldukları, taziyenin sağlıklı yürütülmesinde aktif rol oynadıkları ve taziye sahibine bu konuda destek verdikleri görülmüştür.

Araştırmanın sonuçları önem taşıdığı düşünülmekle birlikte; 16 katılımcı ile yürütülmüş olması ve sadece repertory grid görüşme tekniğine dayalı olarak verilerin elde edilmiş olması bu araştırmanın sınırlılıklarını oluşturmaktadır. Bu nedenle araştırmanın sonuçlarından hareketle şu önerilerde bulunulmaktadır:

- Taziye evlerinin toplumsal yaşamdaki yeri ve önemi, insanları üzerindeki psikolojik etkilerine yönelik sonuçlar için daha kapsamlı çalışmaların yapılmasına ihtiyaç duyulmaktadır. Dolayısıyla ilgili araştırmacılar taziye evleri ve taziye süreçleri ile ilgili Türkiye'nin farklı bölgelerinde çalışma yürütüp elde edilen bulgular üzerinde karşılaştırma yapabilirler.

- Taziye evleri kurulmadan önce, yaşanan taziyelerin yas süreci üzerindeki etkileri ile taziye evleri kurulduktan sonra taziye ve yas üzerindeki etkileri ve farklılıkları çalışılabilir.

\section{Kaynakça}

Adams-Weber, J. (1989) Some reflections on the "meaning" of repertory grid responses. International Journal of Personal Construct Psychology, 2(1), 77 92.

Albayrak, A. \& Arıc1, İ. (2007).. Elazı̆̆'da Taziye Geleneği. Illahiyat Fakültesi Dergisi12:2;33-44.

Ataman, E. \& Barış, İ. (2019). Sosyal Sermaye Ürünü Olarak Taziye Kültürü ve Kurumsal Bir Hizmet Olarak Yas Danışmanlığı: Türkiye-Almanya Örneği. Artvin Çoruh Üniversitesi Uluslararası Sosyal Bilimler Dergisi, 5(2), 93-112.

Balı, H. (2019). Modern dönemde taziye geleneği: Taziye evleri (Batman Örneği). (Yayımlanmamış Yüksel Lisans Tezi). Necmettin Erbakan Üniversitesi/Sosyal Bilimler Enstitüsü. Konya.

Coşkun, O. \& Kayserili, A. (2019). Köklü Bir Kültürün Uzantısı Olarak Ağrı'da Taziye Evleri. Atatürk Üniversitesi Sosyal Bilimler Enstitüsü Dergisi, 23(3), 1109-1130.

Creswell, J.W. ( 1998 ). Qvatitative inquiry and research design: Choosing among five traditions Thousand Oaks, CA: Sage.

Çiçek, İ. (2020). Çocuk psikolojisi ve ruh să̆lı̆̆l. Ankara: Eğiten Kitap.

Demir, A. (2012). Diyarbakır'da taziye geleneği, (Yayımlanmamış Yüksek Lisans Tezi). Dicle Üniversitesi/Sosyal Bilimler Enstitüsü, Diyarbakır.

Dikmen, A. (2015). Değişik Din ve Mezhep Müntesiplerinin Ölümle Gelen Sosyal Birliktelik Algıları ve Ölümü İçselleştirme Uygulamaları (Diyarbakır Örneği) Journal of International Social Research, 8(40). 458-465.

Ertan, M . (2012). Sosyolojik Açıdan Batman ve Yöresindeki 'Taziye Geleneği' ve Bu Geleneğin Anadolu Taziye Kültürü ile Karşılaştırılması. Batman Üniversitesi Yaşam Bilimleri Dergisi, 1 (1), 949-962.

Fransella, F., Bell, R., \& Bannister, D. (2004). A manual for repertory grid technique. John Wiley \& Sons. Ltd.

Kelly, G. A. (1955). The psychology of personal constructs. New York: W. W. Norton.

Mayring, R. (2000). Nitel sosyal araştırmaya giriş ( Çev. Gümüş, A. ve Durgun, M.S.). Adana: Baki Kitabevi.

Melrose, S., \& Shapiro, B. (1999). Students' perceptions of their psychiatric mental health clinical nursing experience: a personal construct theory exploration. Journal of Advanced Nursing, 30(6), 1451-1458.

Morrison, P. (1990). An example of the use of repertory grid technique in assessing nurses self- perceptions of caring. Nurse Education Today, 10, 253-259.

Mumford, Lewis (2007). Tarih boyunca kent, (Çev. Koca, G. ve Tosun, T.). İstanbul: Ayrıntı Yayınları. 
Öncü, A. (1999). İdealinizdeki Ev Mitolojisi Kültürel Sınırları Aşarak İstanbul'a Ulaştı. Birikim, 123(7), 26-34.

Örnek, S. V. (1979). Anadolu folklorunda ölüm (2. Bask1), Ankara Üniversitesi DTCF Yayınları

Parin, S., Bilgili, A. E., \& Menak, Z. (2012). Kent(li)leşme Pratiğinde Yeni Bir Olgu: Taziye Evleri ve Farklılaşan Sosyo-Kültürel Pratikler. YDÜ. Sosyal Bilimler Dergisi, 5:2, 212-219.

Sami, K. (2017). Göç ve Kent(li)leşme Bağlamında Taziye Ev(ler)inin Toplumsal, Kültürel ve Mekânsal Dönüşümleri-Diyarbakır Kent Örneği. Electronic Turkish Studies, 12(13). 457-476.

Shaw, M.L.G. \& Gaines, B. R. (1993). A methodology for analyzing terminological and conceptual differences in language use across communities. In R. Kohler and B. B. Rieger (Eds.) Contributions to quantitative linguistics (pp. 91-138). The Netherlands: Kluwer Academic Publishers.

Tanhan, E. (2018). Beden ĕgitimi ögretmenlerinin program geliştirmeye ilişkin bilişsel kurgularının incelenmesi. (Yayımlanmamış yüksek lisans tezi). Van Yüzüncü Y1l Üniversitesi/Eğitim Bilimleri Enstitüsü. Van.

Tanhan, F. \& İnci, F. A. (2009). Ölüm eğitimi, Ankara: Pegem Akademi.

Yıldırım, A. \& Şimşek, H. (2000). Sosyal bilimlerde nitel araştırma yöntemleri. Ankara: Seçkin Yayın.

Yılmaz Çildam, S. (2020). Yas coğrafyası kapsamında köklü bir kültür örneği: Siirt taziye evleri. Turkish Studies,

15(3), 2093-2114 


\section{Extended Abstract}

Introduction: The absence of the deceased is a situation that takes some time to be accepted by his family and other relatives. Because "mourning", which is the feeling left by the reality of death in the relatives of the deceased, stands as an inevitable element of life. In this context, the support of the individual in the mourning process, firstly by his family and close friends, and then by the people with whom he is connected in his social environment, is undoubtedly an indication that the individual is not alone (Ataman \& Barış, 2019) and that his pain is shared. As a matter of fact, the behaviours that emerged as a result of people getting differen feelings in the face of the reality of death and trying to understand these feelings and make sense of them in their minds turned into stereotypes over time and gained traditional ritual features. Condolence, which is a custom performed by the family and relatives of the deceased person in social life, is also one of the practices mentioned (Albayrak \& Arıc1, 2007).

Determining the place, importance and effects of condolence houses in social life can only be possible by determining the cognitive constructs of the people living in the places where the condolence houses are located. Because it is thought that especially condolence houses have important functions in terms of social solidarity and sharing pain for individuals who have lost their beloved relatives in their mourning processes in a healthy way. In this context, cognitive constructs show the mental relationships between the experiences and knowledge of individuals. In this study, the repertory grid technique was used to reveal the cognitive constructs of the participants in the study and determine the importance and functions of condolence houses.

Method: This study is a qualitative research. Part of qualitative research deals with the way in which the concept or phenomenon takes place in one's mind, rather than starting from a particular theory. Since this study focuses on obtaining what exists in the mind of the person regarding the condolence house phenomenon, the phenomenological design, one of the qualitative research methods, was used in the study. Phenomenological patterns are mostly aimed at revealing the structures of consciousness that form the inner world of the person (Mayring, 2000, Tanhan, 2018).

The data in the study were collected by simple repertory grid interview technique. For this purpose, the Repertory Grid Measurement Form (RGF) was used in the study. RGF is a form developed in line with the acceptances of Grounded Theory known as Embedded Theory. This form is used to determine the cognitive construct of a person on a particular subject. A simple repertory interview form, available in the literature, was used. In this study, the RGF created by the researchers was used in accordance with the modelling of the "repertory grid" (Morrison, 1990; Tanhan, 2018)

Results: 16 (sixteen) people participating in the study produced a total of 160 (one hundred sixty) cognitive constructs. These cognitive constructs were grouped according to their similarities and according to the knowledge of the cognitive constructs in that group, in which cognitive construct group was voiced. Accordingly, a total of four cognitive fiction groups were formed: Death and Grief, Sadness - Crying and Suffering, Fear of Death - Prayer and Hereafter Belief, Social Solidarity Condolence and Traditional Rituals. Analyses were made in which the contribution rate of each participant who contributed to these fiction groups was determined and the importance level of the fiction group compared to the other fiction group was determined; and as a result of these analyses, the relative importance order of the fiction groups was established. The relative importance order of the cognitive construct groups produced by the participants was as follows: 1. Death and Grief ( $\overrightarrow{\mathrm{x}}$ $=65.24)$; in the second row, "Sadness, Crying and Suffering" $(\bar{x}=45.66)$; in the third place, the "Social Solidarity, Condolences and Traditional Rituals" ( $\bar{x}=45.43)$ and in the fourth place is the cognitive fiction group "Fear of Death, Prayer and the Hereafter" $(\bar{x}=34.39)$. Based on these findings, it is seen that the participants generally associate the cognitive construct of "death and mourning" regarding condolence houses.

Considering the arithmetic averages for female and male participants, the first cognitive construct group did not change according to the gender variable. However, the cognitive construct groups in the second, third and fourth places differed. According to this, while female participants considered the fiction group "Sadness, Crying and Suffering" as the second most important in terms of the arithmetic average of the fiction groups; male participants considered the "Social Solidarity, Condolences and Traditional Rituals" fiction group as the second important. The first three fictional groups, which the female participants considered relatively important in terms of arithmetic averages, constituted the "Death and Mourning", "Sorrow, Crying and Suffering" and "Fear of Death, Prayer, and the Hereafter Belief", respectively. For the male participants, the first three fictional groups, which they considered relatively important in terms of arithmetic averages, were "Death and Mourning", "Social Solidarity, Condolence and Traditional Rituals" and "Sadness, Crying and Suffering", respectively.

Discussion \& Conclusion: It was observed that the participants combined the mourning and death cognitive constructs of condolence houses. It can be concluded that they have a perception that it is important to engage and share pain around a painful situation such as mourning and death. Indeed, Albayrak and Arıc1 (2007) in their study performed in Turkey, stated that the tradition of condolence, where sorrows were shared, and the disgruntled people make peace, and social relationships are strengthened, is a very mighty element providing the social integrity. Hence, it can be said that it is psychologically beneficial for the condolence owner or the owners to pour out their hearts and share their feelings to those who come to support them and share their pain. In this context, Ataman and Barış (2019) stated in their study that sharing their feelings by talking to others enables mourning individuals to process their pain in their minds and this makes it easier for them to cope with their pain.

Considering the arithmetic averages for female and male participants, the first cognitive construct group does not change according to the gender variable. However, the cognitive construct groups in the second, third and fourth places differ. From this point of view, while the first cognitive fiction order of the condolence houses of the female and male participants is the same, the relative "Sadness, Crying and Suffering" fiction group in the second place regarding the condolence houses is the women; The male participants, on the other hand, see the "Social Solidarity, Condolence and Traditional Rituals" fiction group important. In this context, it can be said that while women prioritize an emotionally supported mourning process focused on sadness and crying in the context of their emotional structures after the loss, men are more involved in the activities that should be carried out in the mourning process and a traditional solidarity-focused mourning process. As a matter of fact, Parin, Bilgili, and Menak (2012) emphasize that the traditional condolence ritual is represented by women and men in different ways. It is stated that women show themselves more on an emotional front that cries and laments, while men show themselves with a behaviour sequence that tries to be more resilient. Similarly, in the study conducted by Coşkun and Kayserili (2019), it was found that unlike men, women stay outside of their condolence houses and the incoming guests are hosted by women in their home environment. These results show that men's and women's fictions about condolence houses are different.

As a result, when the primary cognitive constructs regarding condolence houses are examined;

In condolence houses, it was observed that social support was provided for the condolence holder to live and survive his life in a healthy way.

In the cognitive constructs of women's condolence houses, it was observed that death and mourning took the first place, namely, being right next to the condolence owner, sharing mourning, and in the second place sadness, crying and suffering, that is, emotional experiences and sharing.

It was determined that death and mourning were in the first place in the cognitive constructs regarding condolence houses of men. In other words, it is a priority to be right next to the owner of the condolence, to be in the burial process, to be a partner of the mourning. In the second place, it was observed that men were steadfast in the context of social solidarity, condolence process and traditions, played an active role in the healthy conduct of condolence and supported the condolence owner in this regard.

Although the results of the research are thought to be important; The limitations of this study are that it was conducted with 16 participants and that the data obtained only were based on the repertory grid interview technique. Therefore, more comprehensive studies are needed to examine the place and importance of condolence houses in social life and their psychological effects on people. Therefore, the respective researchers, in different regions of Turkey, are recommended to conduct related studies to compare findings obtained about home of condolence. 


\title{
EK-1. Etik Kurul Kararı
}

Evrak Tarih ve Sayısı: 02/04/2020-25663

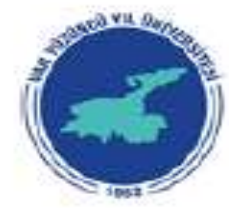

T.C.

VAN YOZÜNCÖ YIL ONIVERSITESI REKTÖRLOGO

Sosyal ve Beşeri Bilimleri Etik Kurulu

Say1 : $85157263-604.01 .02-$ E.25663

$02 / 04 / 2020$

Konu : 9. Dr. Ögr. Oyesi Selami

TANRIVERDI'ye ait çalışma hk.

alman kurul karan

\author{
Sayın Dr. Ögr. O. Selami TANRIVERDI
}

Sosyal ve Beșeri Bilimleri Yayın Etik Kurulu'nun, 27/03/2020 tarih ve 2020/02-09 sayılı karan gereği; Van Özalp Sosyal Yardımlaşma ve Dayanışma Vakfi Sosyal Yardım ve İnceleme Görevlisi Ersin GÜLTEKIN ve Batman Universitesi Cocuk Gelişimi Bölümü Dr. Öğr. Oyesi Illhan ÇIÇEK ile birlikte yapmayı tasarladığınız, "Sosyo-Kültürel Bir Olgu Olan Taziye Evlerine ilişkin Bilişsel Kurgularn Belirlenmesi" adh çalı̧manızla ilgili kurulumuz tarafindan alınan karar ekte sunulmuştur.

Gereğini bilgilerinize rica ederim.

e-imzalıdır

Prof. Dr. Orhan DENIZ

Etik Kurulu Başkamı

Ek: 9. Dr. Öğr. Üyesi Selami TANRIVERDỉye ait çalışma hk. ahnan kurul kararı 
Evrak Tarih ve Sayıs: 01/04/2020-25474

\begin{tabular}{|l|c|}
\hline & T.C. \\
VAN YÜZÜNCÜ YIL UNIVERSITESI \\
SOSYAL VE BESERI BILIMLERI YAYIN \\
ETIK KURUL BASTKANLIGI \\
ETIK KURUL KARARLARI
\end{tabular}

Van Yüzüncü Yal Üniversitesi Sosyal ve Beşeri Bilimleri Yayın Etik Kurulu'nun 27/03/2020 tarihinde saat 10.00' da Van Yüzüncü Y 11 Üniversitesi Strateji Daire Başkanlığı toplantı salonunda Prof. Dr. Orhan DENIZ başkanlığında y apmış olduğu toplantıda aşağıdaki karar/kararları almıştır:

KARAR NO 2020/02-09. Eğitimi Fakültesi, Eğitim Bilimleri Bölümü, Rehberlik ve Psikolojik Danışma Anabilim Dah oggretim üyesi, Dr. Öğr. Üyesi Selami TANRIVERDİnin, Van Özalp Sosyal Yardımlaşma ve Dayanışma Vakfı Sosyal Yardım ve Inceleme Görevlisi Ersin GÜLTEKIN ve Batman Üniversitesi Cocuk Gelişimi Bölümü Dr. Öğr. Üyesi İthan CIÇEK ile birlikte yapmayı tasarladığı, "Sosyo-Kültürel Bir Olgu Olan Taziye Evlerine ilişkin Bilişsel Kurgularn Belirlenmesi" adlı çałı̧mada kullanılacak olan araçlar incelenmiş olup, söz konusu araçların ilgili kişilere uygulanmasında Sosyal ve Beşeri Etik Kuralları ve Ilkeleri çerçevesinde herhangi bir sakınca olmadığına karar verilmiştir.

\begin{tabular}{|c|c|c|}
\hline & $\begin{array}{c}\text { BASKAN } \\
\text { Prof. Dr. Orhan DENL } \\
\text { Edebiyat Fakultesi }\end{array}$ & \\
\hline OYE & OYE & EYE \\
\hline $\begin{array}{c}\text { Prof. Dr. Mehmet Sirin CIKAR } \\
\text { Ilahiyat Fakültesi }\end{array}$ & $\begin{array}{c}\text { Prof. Dr. Hayati AYDIN } \\
\text { Ilahiyat Fakültesi } \\
\text { (Katil madi) }\end{array}$ & $\begin{array}{l}\text { Prof. Dr. Reha SAYDAN } \\
\text { tktisadi ve Id. Bil. Fakiltesi }\end{array}$ \\
\hline OYE & OYE & OYE \\
\hline $\begin{array}{c}\text { Prof. Dr. Metin AYTŞIGI } \\
\text { Edebiyat Fakiltesi }\end{array}$ & $\begin{array}{c}\text { Prof. Dr. Hasan ClCEK } \\
\text { Egitim Fakultesi }\end{array}$ & $\begin{array}{c}\text { Prof. Dr. Zihni MEREY } \\
\text { Egitim Fakiltesi } \\
\text { (Kathlmadi) }\end{array}$ \\
\hline
\end{tabular}

